\title{
Growth and Yield of Summer Sesamum (Sesamum indicum L.), Dry Weight of Weeds and Weed Control Efficiency Influence by Different Row Spacing and Weed Management under South Gujarat Condition
}

\author{
Deep Singh Rajpurohit ${ }^{1 *}$, L.K. Arvadia ${ }^{2}$ and Rameti Jangir ${ }^{1}$ \\ ${ }^{1}$ Department of Agronomy, N. M. College of Agriculture, Navsari Agricultural University, \\ Navsari-396450, India \\ ${ }^{2}$ Department of Agronomy, ASPEE College of Horticulture and Forestry, NAU, \\ Navsari- 396450, India \\ *Corresponding author
}

\section{A B S T R A C T}

\section{Keywords}

Growth and yield, Summer sesamum, Spacing and weed management

Article Info

Accepted:

21 June 2017

Available Online:

10 August 2017
A field experiment was conducted during summer season of 2016 at College Farm, N. M. College of Agriculture, Navsari Agricultural University, Navsari with Fourteen treatment combinations. Treatments were replicated thrice as per randomized block design with factorial concept. Significantly higher values of plant height $(85.70 \mathrm{~cm})$, number of leaves plant $^{-1}(61.03)$, number of branches plant ${ }^{-1}$ (4.66), dry matter accumulation (15.26 g plant $\left.{ }^{1}\right)$, number of capsules plant ${ }^{-1}(57.00)$, number of seeds capsule ${ }^{-1}(62.45)$, length of capsule (3.19), seed yield $\left(802 \mathrm{~kg} \mathrm{ha}^{-1}\right)$ and straw yield $\left(1731 \mathrm{~kg} \mathrm{ha}^{-1}\right)$ were recorded with row spacing of $45 \mathrm{~cm} \times 10 \mathrm{~cm}$. Likewise, significantly maximum plant height $(96.84 \mathrm{~cm})$, number of leaves plant ${ }^{-1}(74.22)$, number of branches plant ${ }^{-1}(5.12)$, dry matter accumulation (17.86 g plant $\left.{ }^{-1}\right)$, number of capsules plant ${ }^{-1}(68.20)$, number of seeds capsule $^{-1}(70.80)$, length of capsule (3.47), seed yield $\left(972 \mathrm{~kg} \mathrm{ha}^{-1}\right)$ and straw yield (1924 $\mathrm{kg} \mathrm{ha}^{-1}$ ) were obtained with $\mathrm{W}_{7}$ (Pendimethalin $1.0 \mathrm{~kg} \mathrm{ha}^{-1}$ as PE $f b$ quizalofop-P-ethyl 40 $\mathrm{g} \mathrm{ha}^{-1}$ at $20 \mathrm{DAS} f b \mathrm{H}$. W. at $\left.40 \mathrm{DAS}\right)$. Significantly lowest dry weight $\left(377.60 \mathrm{~kg} \mathrm{ha}^{-1}\right)$ of total weeds was noted under treatment $S_{1}(30 \mathrm{~cm} \times 10 \mathrm{~cm})$. In weed management treatments $\mathrm{W}_{7}$ recorded markedly lower value of dry weight $\left(270.52 \mathrm{~kg} \mathrm{ha}^{-1}\right)$ of total weeds. Hence the crop sown with wider row spacing and weed management with integration of all methods showed favourable growth leads to higher yield of sesamum.

\section{Introduction}

Oilseeds are backbone of agricultural economy of India since long and considered as the second largest agricultural commodity in India after cereals (Yadav, 2011). Oilseeds are rich source of energy and nutrition. Edible oils and oil meals play pivotal role in solving the problem of malnutrition and securing the calorie nutrition for whole animal kingdom including human beings. Oilseed crops occupy an area of 28.05 million hectares with total production of 32.74 million tonnes and productivity $1168 \mathrm{~kg} \mathrm{ha}^{-1}$ at national level during 2013-14 (Anonymous, 2016a). Sesamum alone occupies an area of 1.7 million hectare with the total production of 0.7 million tonnes and productivity of $426 \mathrm{~kg}$ $\mathrm{ha}^{-1}$ during 2013-14 among all the major oilseed crops (Anonymous, 2016b). Sesamum stands at third position in terms of total oilseed area and fourth in terms of total 
oilseed production in India. The average yield of sesamum is very low $\left(274 \mathrm{~kg} \mathrm{ha}^{-1}\right)$. Sesamum (Sesamum indicum L.) which is variously known as til, simsim, benised, gingelly, gergelim, etc. is one of the most important and extensively grown oilseed crops in India. The sesamum seeds are useful in confectionary and in religious rites. Being rich in protein, calcium, phosphorus and vitamin $\mathrm{E}$, the sesamum cake are valuable cattle feed for farm and dairy animals. Sesamum "The queen of the oilseed crops" by virtue of the excellent quality of the oil, flavour, taste and softness. Its oil content generally varies from 46 to $52 \%$. It is eaten as raw or either roasted or parched and mixed in many kitchen items. Commercially sesamum oil is used directly in pharmaceutical industries in plastering and manufacturing of soaps. Moreover, it is also used as hair oil, body lotion and fixative in perfume industries in cosmetics and adulterant with olive oil and "vanaspati ghee".

Growth, development and final yield of sesamum are mainly affected by the space available to plants; however, the precise and exact response will be species and cultivar specific. So, it is imperative to adjust plant population through row spacing which may help in avoiding excessive crowding and thereby enabling the plants to utilize these resources more effectively and efficiently resulting in increased production. Higher plant population per unit area beyond an optimum limit results in competition among the plants for natural resources, resulting into weaker plant and may cause severe lodging. Linear increase in grain yield has been reported with increase in plant density until other production factors become limiting (Norsworthy and Emerson, 2005). While, low density population produce more branches that carry fertile pods, thus prolonging the seed development phase. Weed competition in sesamum is maximum between 15 and 45
DAS (Duary. and Hazra, 2013). Weeds are one of the major constraints for the poor yield of sesamum crop as they compete with the crop plants for moisture, nutrients, light and space and $50-75 \%$ yield reduction cause by weeds in sesamum crop (Bhadauria et al., 2012b). The weeds in many fields are capable of reducing yields by $79-80 \%$, if left uncontrolled (Shaalan et al., 2014).

\section{Materials and Methods}

In order to study the "summer sesamum (Sesamum indicum L.) Growth and yield as influenced by different row spacing and weed management under south Gujarat condition". A field experiment was conducted at College Farm, Navsari Agricultural University, Navsari throughout summer season of 2016. Navsari Agricultural University campus is geographically located at $20^{\circ}-57^{\prime} \mathrm{N}$ latitude and $72^{\circ}-54^{\prime} \mathrm{E}$ longitude at an altitude of 10 meters above the mean sea level. According to agro-climatic condition, Navsari is located in south Gujarat heavy rainfall zone-I (Agroecological situation-III). The climate of this zone is typically tropical, characterized by humid and warm monsoon with heavy rain, quite cold winter and fairly hot summer. The average annual rainfall of the tract is about $1500 \mathrm{~mm}$. The soil of the experimental field was clayey in texture and showed low, medium and high rating for available nitrogen (197.26 kg ha-1), phosphorus (30.93 $\mathrm{kg} \mathrm{ha}^{-1}$ ) and potassium $\left(369.80 \mathrm{~kg} \mathrm{ha}^{-1}\right)$, respectively. The soil was found slightly alkaline $(\mathrm{pH} 7.8)$ with normal electrical conductivity $\left(0.36 \mathrm{dsm}^{-1}\right)$.

The experiment was conducted with total fourteen treatment combinations consisting of two levels of row spacing viz., $S_{1}: 30 \mathrm{~cm} \mathrm{x} 10$ $\mathrm{cm}, S_{2}: 45 \mathrm{~cm} \times 10 \mathrm{~cm}$ and seven levels of weed management practices viz., $\mathrm{W}_{1}$ : Weedy control, $\mathrm{W}_{2}$ : I. C. at 20 DAS $f b \mathrm{H}$. W. at 40 DAS (Farmers practice), $\mathrm{W}_{3}$ : Pendimethalin $1.0 \mathrm{~kg} \mathrm{ha}^{-1}$ as PE application, $\mathrm{W}_{4}$ : 
Pendimethalin $1.0 \quad \mathrm{~kg}^{\mathrm{ha}} \mathrm{ha}^{-1}$ as PE $f b$ quizalofop-P-ethyl $40 \mathrm{~g} \mathrm{ha}^{-1}$ at $20 \mathrm{DAS}, \mathrm{W}_{5}$ : Oxadiargyl $90 \mathrm{~g} \mathrm{ha}^{-1}$ as PE application, $\mathrm{W}_{6}$ : Oxadiargyl $90 \mathrm{~g} \mathrm{ha}^{-1}$ as PE $f b$ quizalofop-Pethyl $40 \mathrm{~g} \mathrm{ha}^{-1}$ at $20 \mathrm{DAS}$ and $\mathrm{W}_{7}$ : Pendimethalin $1.0 \mathrm{~kg} \mathrm{ha}^{-1}$ as PE $f b$ quizalofop-P-ethyl $40 \mathrm{~g} \mathrm{ha}^{-1}$ at $20 \mathrm{DAS}$ and $\mathrm{H}$. W. at 40 DAS, were evaluated with factorial randomized block design with three replications.

The investigation was carried out with the sesamum variety GT-3. Spraying of herbicide pre-emergence pendimethalin and post emergence quizalofop-P-ethyl was done at 2 DAS and 20 DAS respectively as per treatment. The observations for different characters were recorded at different periodical intervals. The statistical analysis of data was carried out through the procedure appropriate to the randomized block design with factorial concept of the experiment as described by Panse and Sukhatme (1967).

The observations for different characters were recorded at different periodical intervals. For biometric observation five plants were selected at random from each net plot and tagged for recording periodical growth and yield attributing parameters. The numbers of days required from the date of sowing to date at which 50 per cent plants have come to flowering were recorded as days to 50 per cent flowering for each treatment.

For recording dry matter accumulation by plant randomly five plants were dug out from the border area and expressed as g plant ${ }^{-1}$. In case of weed dry matter accumulation the weed samples were collected from $1.0 \mathrm{~m}^{2}$ area and expressed as $\mathrm{g} \mathrm{m}^{-2}$ and finally at the time of harvest from entire net plot area of each plot and expressed as $\mathrm{kg} \mathrm{ha}^{-1}$. After removing the roots, the above ground plant parts and whole weed samples were first sun dried and finally oven dried at $65{ }^{\circ} \mathrm{C}$ for 72 hours up to constant dry weight.
The harvest index (\%) was computed by using the formula suggested by Donald (1963) and recorded separately for each treatment.

$$
\mathrm{HI}(\%)=\frac{\text { Economical yield }\left(\mathrm{kg} \mathrm{ha}^{-1}\right)}{\text { Biological yield }\left(\mathrm{kg} \mathrm{ha}^{-1}\right)}
$$

The weed control efficiency was calculated by using the following formula (Kondap and Upadhyay, 1985).

$\operatorname{WCE}(\%)=\frac{\text { DWC }- \text { DWT }}{\text { DWC }}$

Where, DWC and DWT were the weed dry weight in control and treated plots, respectively.

\section{Results and Discussion}

\section{Study on plant}

\section{Effect of row spacing}

Wider row spacing $\mathrm{S}_{2}(45 \mathrm{~cm} \times 10 \mathrm{~cm})$ produce significantly taller plant $(85.70 \mathrm{~cm})$, maximum number of leaves pant $^{-1}$ (61.03) and maximum number of branches plant ${ }^{-1}(4.66)$ over narrow spacing $30 \mathrm{~cm} \times 10 \mathrm{~cm}\left(\mathrm{~S}_{1}\right)$. The probable reasons for higher plant height, more number of leaves and more number of branches plant ${ }^{-1}$ might be due to relatively competition free environments prevail, hence more availability of nutrients, greater light interception, efficient utilization of soil moisture and space under lower degree of inter-plant competition. Almost similar findings were also reported by Ali et al., (2005) at Faisalabad, Pakistan and Shekh et al., (2014) at Junagadh. The significantly higher dry matter production plant ${ }^{-1}(15.26 \mathrm{~g}$ plant $\left.^{-1}\right)$ was recorded under treatment $S_{2}(45$ $\mathrm{cm} \times 10 \mathrm{~cm})$. The increase in plant vigour in terms of height, number of leaves and 
branches plant ${ }^{-1}$, with wider row spacing was found to be useful in utilizing the radiant energy more effectively, ultimately lead to increased synthesis of carbohydrate and production of more dry matter plant ${ }^{-1}$. The present result is close conformation with Hemalatha et al., (1999) at Tirupati (A.P.) and Patel (2012) at S.D.A.U., Gujarat. Whereas, non-significant difference was observed in days to 50 per cent flowering due to different row spacing (Table 1). While, contradictory results reported in this regard by Haruna (2011) and Monpara and Vaghasia (2016). Significantly higher values for the yield attributing characters, viz., number of capsules plant ${ }^{-1}(57)$, number of seeds capsule 1 (62.45), and length of capsule $(3.19 \mathrm{~cm})$ were recorded under treatment $S_{2}(45 \mathrm{~cm} \times 10$ $\mathrm{cm})$. The better development of various yield attributes might be due to low degree of inter plant competition for moisture, nutrients, solar energy and more availability of resources for development of individual plant, reflecting in higher vegetative growth. As a result of better partitioning of photosynthates from source to sink, development of yield attributes was better under wide row spacing. This result was consistent with the results observed by Hemalatha et al., (1999) at Tirupati (A. P.); Tahir et al., (2012) at Faisalabad (Pakistan) and Shekh et al., (2014) at Junagadh (Gujarat). Non-significant difference was observed in 1000 seed weight of sesamum due to different row spacing. That may be due to the fact that grains act as strong physiological reservoirs and rarely respond to the treatments like row spacing. The present result is in close conformation with Ghungarde et al., (1992) at Parbhani; Ali et al., (2005) at Faisalabad, Pakistan. While, Hemalatha et al., (1999) Tirupati (A.P.); Shekh et al., (2014) at Junagadh (Gujarat) and Monpara and Vaghasia (2016) at Amreli (Gujarat) reported contradictory results with respect to the 1000 seed weight which was significantly influenced by different row spacing. Significantly higher grain yield (802 $\left.\mathrm{kg} \mathrm{ha}{ }^{-1}\right)$ and straw yield (1731 kg ha $\left.{ }^{-1}\right)$ obtained under treatment $S_{2}(45 \mathrm{~cm} \times 10$ $\mathrm{cm})$.It was due to the overall better growth performance and higher values of most of the yield attributes under wider row spacing resulted into significantly higher grain yield with treatment $S_{2}$. Better development of various growth parameters such as plant height, number of branches plant ${ }^{-1}$ and dry matter accumulation ultimately reflected into significantly higher straw yield under treatment $S_{2}$. It was probably due to optimum plant population per unit area which gave optimum yield per plant and lower plant competition. The wider row spacing improved individual plant yield and yield per unit area is the resultant of cumulative yield from individual plants per unit area. A narrow row spacing sown crops have more number of plants per unit area and reduction in yield per plant might not to be compensated with yield from more number of plants per unit area. These results are in agreement with those of Ali et al., (2005) at Faisalabad, Pakistan. While, Hemalatha et al., (1999) at Tirupati (A.P.); Shekh et al., (2014) at Junagadh (Gujarat) and Prasannakumara et al., (2014) at Dharwad reported contradictory results in this regard. Harvest index remained unaffected due to different row spacing (Table 2).

\section{Effect of weed management}

Treatment $\mathrm{W}_{7}$ recorded the maximum plant height $(96.84 \mathrm{~cm})$ but remained statistically at par with treatments $\mathrm{W}_{2}$ and $\mathrm{W}_{4}$. Significantly the maximum number of leaves plant ${ }^{-1}$ (74.22) were recorded with treatment $\mathrm{W}_{7}$ but it was statistically at par with treatment $\mathrm{W}_{2}$. Significantly higher number of branches plant $^{-1}$ (5.12) was observed with $\mathrm{W}_{7}$, but it being statistically at par with $\mathrm{W}_{2}$ and $\mathrm{W}_{4}$. The maximum values of all the growth parameters in these treatments $\left(\mathrm{W}_{7}, \mathrm{~W}_{2}\right.$ and $\left.\mathrm{W}_{4}\right)$ and 
lowest value in treatment $\mathrm{W}_{1}$ (weedy control) might be due to the reasons that application of pendimethalin as pre-emergence gave better control of weeds from very beginning at an early stage and reduced early weed competition lead to more nutrient and soil moisture available to the crop which enhanced vegetative growth of sesamum. The results are in agreement with the findings of Svathi et al., (2005) at Karaikal and Mathukia et al., (2015) at Junagadh (Gujarat). Nonsignificant difference was observed in days to 50 per cent flowering due to various weed management treatments applied to sesamum.
Significantly maximum dry matter production plant $^{-1}$ (17.86 g plant $\left.{ }^{-1}\right)$ was recorded with treatment $\mathrm{W}_{7}$ but it was statistically at par with treatment $\mathrm{W}_{2}, \mathrm{~W}_{4}$ and $\mathrm{W}_{6}$ at 60 DAS.

Significantly the lowest dry matter plant ${ }^{-1}$ was produced in weedy control treatment $\left(\mathrm{W}_{1}\right)$ at all the stages of crop growth. This might be due to better growth of plants in terms of plant height, number of leaves and branches plant $^{-1}$, ultimately resulted in higher dry matter accumulation plant ${ }^{-1}$. These results are in agreement with the findings of Mruthul et al., (2015) (Table 2).

Table.1 Effect of different row spacing and weed management treatments on growth and Growth attributes of sesamum

\begin{tabular}{|c|c|c|c|c|c|c|c|c|c|}
\hline \multirow{2}{*}{ Treatments } & \multicolumn{2}{|c|}{ Plant height $(\mathrm{cm})$} & \multicolumn{2}{|c|}{$\begin{array}{c}\text { Number of leaves } \\
\text { plant }^{-1}\end{array}$} & \multicolumn{2}{|c|}{$\begin{array}{c}\text { Number of } \\
\text { branches plant }^{-1}\end{array}$} & \multicolumn{2}{|c|}{ DMA (g plant $\left.{ }^{-1}\right)$} & \multirow{2}{*}{$\begin{array}{c}\text { Days to } \\
\mathbf{5 0 \%} \\
\text { flowering }\end{array}$} \\
\hline & $\begin{array}{c}\text { 60 } \\
\text { DAS }\end{array}$ & $\begin{array}{c}\text { At } \\
\text { harvest }\end{array}$ & $\begin{array}{c}\text { 60 } \\
\text { DAS }\end{array}$ & $\begin{array}{c}\text { At } \\
\text { harvest }\end{array}$ & $\begin{array}{c}\text { 60 } \\
\text { DAS }\end{array}$ & $\begin{array}{c}\text { At } \\
\text { harvest }\end{array}$ & $\begin{array}{c}\text { 60 } \\
\text { DAS }\end{array}$ & $\begin{array}{c}\text { At } \\
\text { harvest }\end{array}$ & \\
\hline \multicolumn{10}{|c|}{ Row spacing (S) } \\
\hline $\mathrm{S}_{1}$ & 71.50 & 76.69 & 60.86 & 56.38 & 4.19 & 4.31 & 10.09 & 13.68 & 38.57 \\
\hline $\mathrm{S}_{2}$ & 81.32 & 85.70 & 65.56 & 61.03 & 4.49 & 4.66 & 10.90 & 15.26 & 39.33 \\
\hline S.Em. \pm & 1.79 & 1.88 & 1.35 & 1.31 & 0.10 & 0.11 & 0.22 & 0.32 & 0.59 \\
\hline C.D. at $5 \%$ & 5.20 & 5.47 & 3.92 & 3.81 & 0.28 & 0.31 & 0.63 & 0.94 & NS \\
\hline \multicolumn{10}{|c|}{ Weed management practices (W) } \\
\hline $\mathrm{W}_{1}$ & 54.46 & 59.83 & 40.33 & 36.00 & 3.86 & 3.77 & 9.09 & 12.73 & 36.50 \\
\hline $\mathrm{W}_{2}$ & 86.73 & 92.71 & 72.52 & 67.68 & 4.66 & 4.87 & 11.31 & 15.04 & 37.27 \\
\hline $\mathrm{W}_{3}$ & 71.77 & 76.10 & 65.77 & 60.10 & 3.86 & 4.06 & 10.60 & 13.66 & 38.82 \\
\hline $\mathrm{W}_{4}$ & 84.41 & 90.08 & 69.13 & 65.80 & 4.69 & 4.79 & 10.97 & 14.11 & 40.81 \\
\hline $\mathrm{W}_{5}$ & 65.87 & 69.70 & 51.08 & 47.92 & 4.16 & 4.43 & 9.84 & 13.30 & 38.91 \\
\hline $\mathrm{W}_{6}$ & 79.29 & 83.13 & 63.90 & 59.23 & 4.25 & 4.39 & 10.68 & 14.60 & 38.98 \\
\hline $\mathrm{W}_{7}$ & 92.34 & 96.84 & 79.72 & 74.22 & 4.92 & 5.12 & 10.98 & 17.86 & 41.36 \\
\hline S.Em. \pm & 3.35 & 3.52 & 2.52 & 2.45 & 0.18 & 0.20 & 0.40 & 0.60 & 1.11 \\
\hline C.D. at $5 \%$ & 9.73 & 10.23 & 7.33 & 7.13 & 0.52 & 0.57 & 1.17 & 1.76 & NS \\
\hline C.V. \% & 10.73 & 10.61 & 9.77 & 10.23 & 10.04 & 10.72 & 9.40 & 10.23 & 6.99 \\
\hline Interaction & $\mathrm{NS}$ & $\mathrm{NS}$ & NS & $\mathrm{NS}$ & NS & NS & NS & NS & $\mathrm{NS}$ \\
\hline
\end{tabular}


Table.2 Effect of different row spacing and weed management treatments on yield and Yield attributes of summer sesamum

\begin{tabular}{|c|c|c|c|c|c|c|c|}
\hline Treatments & $\begin{array}{c}\text { No. of } \\
\text { capsules } \\
\text { plant }^{-1}\end{array}$ & $\begin{array}{c}\text { No. of } \\
\text { seeds } \\
\text { capsule }^{-1} \\
\end{array}$ & $\begin{array}{l}\text { Length of } \\
\text { capsule } \\
(\mathrm{cm})\end{array}$ & $\begin{array}{l}1000 \text { seed } \\
\text { weight } \\
\text { (g) }\end{array}$ & $\begin{array}{c}\text { Seed } \\
\text { yield } \\
\left(\mathrm{kg} \mathrm{ha}^{-1}\right)\end{array}$ & $\begin{array}{c}\text { Straw } \\
\text { yield } \\
\left(\mathrm{kg} \mathrm{ha}^{-1}\right)\end{array}$ & $\begin{array}{c}\text { Harvest } \\
\text { index } \\
(\%)\end{array}$ \\
\hline \multicolumn{8}{|c|}{ Row spacing (S) } \\
\hline $\mathrm{S}_{1}$ & 51.70 & 56.80 & 3.00 & 2.99 & 735 & 1522 & 32.58 \\
\hline $\mathrm{S}_{2}$ & 57.00 & 62.45 & 3.19 & 3.01 & 802 & 1731 & 31.74 \\
\hline S.Em. \pm & 1.20 & 0.99 & 0.05 & 0.04 & 16.78 & 44.96 & 0.45 \\
\hline C.D. at $5 \%$ & 3.47 & 2.88 & 0.13 & NS & 48.79 & 130.72 & NS \\
\hline \multicolumn{8}{|c|}{ Weed management practices $(\mathrm{W})$} \\
\hline $\mathrm{W}_{1}$ & 43.40 & 52.25 & 2.61 & 2.89 & 504 & 1049 & 32.38 \\
\hline $\mathrm{W}_{2}$ & 61.13 & 66.88 & 3.38 & 3.06 & 874 & 1894 & 31.63 \\
\hline $\mathrm{W}_{3}$ & 49.48 & 55.70 & 2.89 & 2.97 & 703 & 1494 & 32.06 \\
\hline $\mathrm{W}_{4}$ & 58.46 & 60.17 & 3.34 & 3.05 & 834 & 1811 & 31.59 \\
\hline $\mathrm{W}_{5}$ & 47.73 & 53.47 & 2.83 & 2.91 & 681 & 1528 & 31.10 \\
\hline $\mathrm{W}_{6}$ & 52.03 & 58.12 & 3.15 & 3.02 & 812 & 1683 & 32.72 \\
\hline $\mathrm{W}_{7}$ & 68.20 & 70.80 & 3.47 & 3.10 & 972 & 1924 & 33.63 \\
\hline S.Em. \pm & 2.24 & 1.85 & 0.09 & 0.08 & 31.39 & 84.11 & 0.85 \\
\hline C.D. at $5 \%$ & 6.50 & 5.38 & 0.25 & NS & 91.28 & 244.55 & NS \\
\hline C.V. \% & 10.07 & 7.60 & 6.84 & 6.29 & 10.01 & 12.67 & 6.44 \\
\hline Interaction & NS & NS & NS & NS & NS & NS & NS \\
\hline
\end{tabular}

Table.3 Dry weight of weeds and WCE \% as influenced by different row spacing and weed Management treatments in summer sesamum

\begin{tabular}{|c|c|c|c|c|c|c|}
\hline \multirow[b]{2}{*}{ Treatments } & \multicolumn{3}{|c|}{ Weed dry weight } & \multicolumn{3}{|c|}{ Weed control efficiency (\%) } \\
\hline & $\begin{array}{c}\text { At } 20 \text { DAS } \\
\left(\mathrm{g} \mathrm{m}^{-2}\right)\end{array}$ & $\begin{array}{c}\text { At } 40 \text { DAS } \\
\left(\mathrm{g} \mathrm{m}^{-2}\right)\end{array}$ & $\begin{array}{l}\text { At harvest } \\
\left(\mathrm{kg} \mathrm{ha}^{-1}\right)\end{array}$ & At 20 DAS & At 40 DAS & At harvest \\
\hline $\mathrm{S}_{1}$ & 13.90 & 26.44 & 377.60 & - & - & - \\
\hline $\mathrm{S}_{2}$ & 14.53 & 32.65 & 431.43 & - & - & - \\
\hline S.Em. \pm & 0.28 & 0.62 & 12.48 & - & - & - \\
\hline C.D. at $5 \%$ & $\mathrm{NS}$ & 1.80 & 36.29 & - & - & - \\
\hline $\mathrm{W}_{1}$ & 19.24 & 52.30 & 771.92 & 0.00 & 0.00 & 0.00 \\
\hline $\mathrm{W}_{2}$ & 16.01 & 22.75 & 282.75 & 16.78 & 56.49 & 63.37 \\
\hline $\mathrm{W}_{3}$ & 13.28 & 32.76 & 443.88 & 30.99 & 37.36 & 42.50 \\
\hline $\mathrm{W}_{4}$ & 12.32 & 20.81 & 323.78 & 35.94 & 60.21 & 58.05 \\
\hline $\mathrm{W}_{5}$ & 14.85 & 35.62 & 432.00 & 22.83 & 31.89 & 44.04 \\
\hline $\mathrm{W}_{6}$ & 13.66 & 24.67 & 306.73 & 29.02 & 52.82 & 60.26 \\
\hline $\mathrm{W}_{7}$ & 10.16 & 17.90 & 270.52 & 47.21 & 65.77 & 64.96 \\
\hline S.Em. \pm & 0.52 & 1.16 & 23.35 & - & - & - \\
\hline C.D. at 5\% & 1.50 & 3.37 & 67.90 & - & - & - \\
\hline C.V. $\%$ & 8.92 & 9.61 & 14.14 & - & - & - \\
\hline Interaction & NS & NS & NS & - & - & - \\
\hline
\end{tabular}

$\mathrm{S}_{1}: 30 \mathrm{~cm} \times 10 \mathrm{~cm}, \mathrm{~S}_{2}: 45 \mathrm{~cm} \mathrm{x10} \mathrm{cm}, \mathrm{W}_{1}$ : Weedy control, $\mathrm{W}_{2}$ : I. C. at 20 DAS $f b \mathrm{H} . \mathrm{W}$. at 40 DAS (Farmers practice), $\mathrm{W}_{3}$ : Pendimethalin $1.0 \mathrm{~kg} \mathrm{ha}^{-1}$ as $\mathrm{PE}$ application, $\mathrm{W}_{4}$ : Pendimethalin $1.0 \mathrm{~kg} \mathrm{ha}^{-1}$ as PE $f b$ quizalofop-Pethyl $40 \mathrm{~g} \mathrm{ha}^{-1}$ at $20 \mathrm{DAS}, \mathrm{W}_{5}$ : Oxadiargyl $90 \mathrm{~g} \mathrm{ha}^{-1}$ as PE application, $\mathrm{W}_{6}$ : Oxadiargyl $90 \mathrm{~g} \mathrm{ha}^{-1}$ as PE $f b$ quizalofop-P- ethyl $40 \mathrm{~g} \mathrm{ha}^{-1}$ at $20 \mathrm{DAS}$ and $\mathrm{W}_{7}$ : Pendimethalin $1.0 \mathrm{~kg} \mathrm{ha}^{-1}$ as PE $f b$ quizalofop-P-ethyl $40 \mathrm{~g} \mathrm{ha}^{-1}$ at 20 DAS and $\mathrm{H}$. W. at 40 DAS. 
The treatment $\mathrm{W}_{7}$ recorded significantly higher values of yield attributing characters viz., number of capsules plant ${ }^{-1}$ (68.20), number of seeds capsule ${ }^{-1}$ (70.80) and length of capsule $(3.47 \mathrm{~cm})$ of above parameters but it remained statistically at par with $\mathrm{W}_{2}$ for numbers of seeds capsule ${ }^{-1}$. While, in case of length of capsule it remained at par with treatment $\mathrm{W}_{2}$ and $\mathrm{W}_{4}$. However, the lowest values of above yield attributes were observed under the treatment $\mathrm{W}_{1}$. This trend of results indicating least competition offered by weeds for nutrients and moisture at crucial growth stages under these treatments ultimately improved all yield attributes besides increased rate of $\mathrm{N}, \mathrm{P}$ and $\mathrm{K}$ absorption as evident from nutrient uptake studies cumulatively helped the crop plants to produce more surface area for high photosynthetic rate as well as maximum translocation of photosynthates from source to sink, subsequently resulted in improvement of above yield attributes. Because of synergist effect among the yield attributes they benefited each other. However, significantly higher seed and straw yield (972 and $1924 \mathrm{~kg} \mathrm{ha}^{-1}$, respectively) recorded under treatment $\mathrm{W}_{7}$ but remained at par with the treatments $\mathrm{W}_{2}, \mathrm{~W}_{4}$ and $\mathrm{W}_{6}$ in case of straw yield only. The remarkable increase in seed and straw yield under these treatments might be due to effective control of weeds, lower dry weight of weeds and higher weed control efficiency as well as lower weed index which cumulatively facilitated the crop to utilize more nutrients and water for better growth and development in terms of various growth attributing characters such as plant height, number of branches plant ${ }^{-1}$ and yield attributing characters. All the parameters showed positive and highly significant influence on seed and straw yield of sesamum. These findings are in accordance with those of Mathukia et al., (2015) at Junagadh; Mruthul et al., (2015) at Raichur. There was no significant effect of weed management treatments with respect to 1000 seed weight and harvest index (Table 2). The contradictory result was recorded in this regard by Mathukia et al., (2015) at Junagadh (Gujarat) in case of 1000 seed weight and Mruthul et al., (2015) at Raichur.

\section{Study on weeds}

\section{Effect of row spacing}

The effect of row spacing on dry weight of weeds at 20 DAS was found to be nonsignificant. While, the lowest dry weight of weeds was also found under narrow spacing treatment $\mathrm{S}_{1}$ i.e. $30 \mathrm{~cm} \times 10 \mathrm{~cm}$ at 40 DAS and at harvest $\left(26.44 \mathrm{~g} \mathrm{~m}^{-2}\right.$ and $377.60 \mathrm{~kg} \mathrm{ha}^{-}$ $\left.{ }^{1}\right)$. That might be due to more number of plants per unit area in narrow row spacing lead to shading effect resulting from the crop canopy, limits availability of resources required for weed germination, emergence and growth. This effect is more pronounced in $30 \mathrm{~cm} \times 10 \mathrm{~cm}$ row spacing. Weed biomass reduction at this period can be explained by the reduction in total incoming photosynthetic active radiation (PAR) reaching the ground and indicates that narrow inter-row spacing increased the competitiveness of the sesamum with weeds. These results are in line with those reported by Patel (2000) in sugarcane; Hussein et al., (2008) in maize; Takim and Adereti (2012) in soybean and Bakht and Khan (2014) in tomato.

\section{Effect of weed management}

The dry weight of weeds recorded at 20, 40 DAS and at harvest were reduced significantly by all weed management treatments as compared to weedy control $\left(\mathrm{W}_{1}\right)$. Treatment $\mathrm{W}_{7}$ recorded the lower dry weight of weeds $\left(10.16 \mathrm{~g} \mathrm{~m}^{-2}, 17.90 \mathrm{~g} \mathrm{~m}^{-2}\right.$ and $270.52 \mathrm{~kg} \mathrm{ha}^{-1}$ at 20,40 DAS and at harvest, respectively) but it was found at par with treatment $\mathrm{W}_{4}$ at $40 \mathrm{DAS}$ while, at harvest it was found at par with treatment $\mathrm{W}_{2}, \mathrm{~W}_{6}$ and 
$\mathrm{W}_{4}$. This might be due to the combination of both cultural and chemical methods which was found to be more effective in suppressing the weed density as well as weed dry matter (Table 3). Various weed management treatments showed better weed control efficiency. The response of different weed management practices in term of weed control efficiency at 20 DAS was remained in order of $\mathrm{W}_{7}>\mathrm{W}_{4}>\mathrm{W}_{3}>\mathrm{W}_{6}>\mathrm{W}_{5}>\mathrm{W}_{2}>\mathrm{W}_{1}$. However, in case of 40 DAS it was remained in order of $\mathrm{W}_{7}>\mathrm{W}_{4}>\mathrm{W}_{2}>\mathrm{W}_{6}>\mathrm{W}_{3}>\mathrm{W}_{5}>$ $\mathrm{W}_{1}$ and at harvest the order was $\mathrm{W}_{7}>\mathrm{W}_{2}>$ $\mathrm{W}_{6}>\mathrm{W}_{4}>\mathrm{W}_{5}>\mathrm{W}_{3}>\mathrm{W}_{1}$. The results have confirmed the findings of Mathukia et al., (2015) and Mruthul et al., (2015).

\section{References}

Ali, A.; Asif, T.; Nadeem, M. A. and Bajwa, A. L. (2005). Effect of sowing dates and row spacing's on growth and yield of sesame. Journal of Agriculture Research (Lahore), 43(1): 19-26.

Anonymous (2016a). Annual Report 2015-16. Department of Agriculture, Cooperation and Farmers' Welfare. Ministry of Agriculture and Farmers' Welfare, Govt. of India, New Delhi. www.agricoop.nic.in

Anonymous (2016b). Agricultural Statistics at a glance. Directorate of Economics and Statistics, Department of Agriculture and Cooperation, Ministry of Agriculture, Govt. of India, New Delhi.

Bakht, T. and Khan, I. A. (2014). Weed control in Tomato (Lycopersicon esculatum Mill.) through mulching and herbicides. Pakistan Journal of Botany, 46(1): 289-292.

Bhadauria, N.; Yadav, K. S.; Rajput, R. L. and Singh, V. B. (2012b). Integrated weed management in sesame. Indian Journal of Weed Science, 44(4): 235237.

Donald, C. M. (1963). Competition among crop and plants. Advances in Agronomy, 15(1): 114.

Duary, B. and Hazra, D. (2013). Determination of critical period of cropweed competition in sesame. Indian Journal of Weed Science, 45(4): 253256.

Ghungarde, S. R.; Chavan, D. A.; Alse, U. N.; Yeagaonkar, G. V. and Pangarkar, V. N. (1992). Effect of plant density and variety on yield of sesame (Sesamum indicum L.). Indian Journal of Agronomy, 37(2): 385-386.

Haruna, I. M. (2011). Growth and yield of sesame (Sesamum indicum L.) as influenced by nitrogen and intra row spacing in Lafia, Nasarawa State of Nigeria. I. $M$. Harunal Elixir Agriculture, 41: 5685-5688.

Hemalatha, S.; Jagannatham, A. and Rao, V. P. (1999). Effect of nitrogen fertilization and row spacing on growth and yield of sesame. Journal of Oilseeds Research, 16(1): 128-129.

Hussein, F. A.; El-Metwally, I. M. and ElDesoki, E.R. (2008). Effect of plant spacing and weed control treatments on productivity of maize and growth of associated weeds in sandy soil. American- Eurasian Journal of Agriculture \& Environment Sciences, 4(1): 09-17.

Kondap, S.M. and Upadhyay, U.C. (1985). A practical manual on weed control. Oxford and IBH publ. Co., New Delhi, pp.55.

Mathukia, R. K.; Sagarka, B. K. and Jadav, C. N. (2015). Integrated weed management in summer sesame. Indian Journal of Weed Science, 47(2): 150-152.

Monpara, B. A. and Vaghasia, D. R. (2016). Optimizing sowing time and row spacing for summer sesame growing in semi-arid environments of India. International Journal of Current Research and Academic Review, 4(1): 
122-131.

Mruthul, T.; Halepyati, A. S. and Chittapur, B. M. (2015). Chemical weed management in sesame (Sesamum indicum L.). Karnataka Journal of Agricultural Science, 28(2): 151-154.

Norsworthy, J. K. and R.S. Emerson (2005). Effect of row spacing and soybean genotype on main stem and branch yield. Agronomy Journal, 97: 919-923.

Panse, V. G. and Sukhatme, P. V. (1967). "Statistical Methods for Agricultural Workers". ICAR, New Delhi.

Patel, H. K. (2012). Response of summer sesame to different spacing's and levels of nitrogen under north Gujarat condition. Thesis submitted to S.D.A.U., Gujarat.

Patel, S. R. (2000). Effect of planting geometry, intercropping and weed management on sugarcane (Saccharum hybrid) var. CoN-91132 (Guj.Cane-1). Ph.D. thesis, submitted to G.A.U., S.K. Nagar.

Prasannakumara, B. H.; Chittapur, B. M.; Hiremath, S. M.; Malligwad, L. H.; Nadaf, H. L. and Koti R. V. (2014). Effect of fertilizer levels and planting geometry on the performance of sesame (Sesamum indicum L.) genotypes. Karnataka Journal Agricultural Science, 27(3): 289-292.

Shaalan, A. M.; Abou-zied, K. A. and El nass, M. K. (2014). Productivity of sesame as influenced by weeds competition and determination of critical period of weed control. Alexandria Journal of Agricultural Research, 59(3): 179- 187. Shekh, M. A.; Mathukia, R. K. and Sagarka, B. K. (2014). Sowing time and spacing for Summer Sesame (Sesamum indicum L.). Agriculture: Towards a New Paradigm of Sustainability. 111-115.

Svathi, A.; Rammohan, J.; Nadanassababady, T. and Chellamuthu, V. (2005). Influence of sowing methods and weed management on sesame (Sesamum indicum) yield under irrigated condition. Journal of crop and weed, 2(1): 4-7.

Tahir, M.; Umer, S.; Asghar, A.; Ishtiaq, H.; Muhammad, N.; Muhammad, I.; Rehman, H. and Hafiz, M. R. J. (2012). Optimizing sowing date and row spacing for newly evolved sesame (Sesamum indicum L.) Variety TH-6. Pakistan journal of life society Science, 10(1): 1-4.

Takim, F. O. and Adereti, R. O. (2012). Effect of inter row spacing and weed management practices on the performance of soybean [Glycine max (L.) Merrill] in the southern Guinea Savanna zone of Nigeria. African Journal of Agriculture Research and Development, 5(1): 76-83.

Yadav, K. (2011). Oilseed scenario in India. Retrieved from http://agropedia.iitk.ac.in

\section{How to cite this article:}

Deep Singh Rajpurohit, L.K. Arvadia and Rameti Jangir. 2017. Growth and Yield of Summer Sesamum (Sesamum indicum L.), Dry Weight of Weeds and Weed Control Efficiency Influence by Different Row Spacing and Weed Management under South Gujarat Condition. Int.J.Curr.Microbiol.App.Sci. 6(8): 2493-2501. doi: https://doi.org/10.20546/ijcmas.2017.608.295 